\title{
Germination and early establishment of dryland grasses and shrubs on intact and wind-eroded soils under greenhouse conditions
}

\author{
Furong Niu (1) - Nathan A. Pierce • \\ Steven R. Archer · Gregory S. Okin
}

Received: 28 January 2021 / Accepted: 10 May 2021 / Published online: 21 May 2021

(C) The Author(s) 2021

\begin{abstract}
Aims Grassland-to-shrubland transition is a common form of land degradation in drylands worldwide. It is often attributed to changes in disturbance regimes, particularly overgrazing. A myriad of direct and indirect effects (e.g., accelerated soil erosion) of grazing may favor shrubs over grasses, but their relative importance is unclear. We tested the hypothesis that topsoil "winnowing" by wind erosion would differentially affect grass and shrub seedling establishment to promote shrub recruitment over that of grass. Methods We monitored germination and seedling growth of contrasting perennial grass (Bouteloua eriopoda, Sporobolus airoides, and Aristida purpurea) and shrub (Prosopis glandulosa, Atriplex canescens, and Larrea tridentata) functional groups on field-collected non-winnowed and winnowed soils under wellwatered greenhouse conditions.

Results Non-winnowed soils were finer-textured and had higher nutrient contents than winnowed soils, but based on desorption curves, winnowed soils had
\end{abstract}

Responsible Editor: Amandine Erktan.

F. Niu $(\bowtie) \cdot$ N. A. Pierce $\cdot$ S. R. Archer

School of Natural Resources and the Environment,

University of Arizona, Tucson, AZ 85721, USA

e-mail: fniu@email.arizona.edu

G. S. Okin

Department of Geography, University of California, Los Angeles, CA 90095, USA more plant-available moisture. Contrary to expectations, seed germination and seedling growth on winnowed and non-winnowed soils were comparable within a given species. The $\mathrm{N}_{2}$-fixing deciduous shrub $P$. glandulosa was first to emerge and complete germination, and had the greatest biomass accumulation of all species.

Conclusions Germination and early seedling growth of grasses and shrubs on winnowed soils were not adversely nor differentially affected comparing with that observed on non-winnowed soils under wellwatered greenhouse conditions. Early germination and rapid growth may give $P$. glandulosa a competitive advantage over grasses and other shrub species at the establishment stage in grazed grasslands. Field establishment experiments are needed to confirm our findings in these controlled environment trials.

Keywords Shrub encroachment · Chihuahuan Desert grassland $\cdot$ Aeolian processes $\cdot$ Prosopis glandulosa $\cdot$ Bouteloua eriopoda $\cdot$ Plant functional group

\section{Introduction}

Shrub encroachment is a widely-observed form of land degradation in many arid and semiarid grasslands globally (Archer et al. 1995; Van Auken 2000). These conversions of grassland to shrubland adversely affect ecosystem function and services, 
including biodiversity (Ratajczak et al. 2012), primary productivity (Knapp et al. 2008), and nutrient, water, and carbon cycling (Eldridge et al. 2011; Hibbard et al. 2001; McCulley et al. 2004), with the magnitude of their effects dependent on context (e.g., precipitation regimes; Knapp et al. 2008; Anadón et al. 2014). This physiognomic transformation is commonly ascribed to changes in disturbance regimes (e.g., livestock overgrazing, fire) interacting within constraints imposed by topoedaphic and climate factors (Archer et al. 2017) and plant-plant interactions (Pierce et al. 2019a, b) that mitigate probabilities and rates of change. Disturbances, such as livestock grazing, one of the most important divers of shrub encroachment, potentially alters grass-shrub competitive interactions by reducing grass foliar and root biomass to potentially shift the competitive balance in favor of shrubs. Various aspects of these direct effects of grazing on grass-shrub interactions have been widely studied. However, indirect effects of grazing also have important consequences for grassshrub interactions in drylands. For example, grazing reduces fine-fuel loads and continuity, thus reducing the likelihood, intensity, and spread of fires that might otherwise prevent shrub proliferation (Madany and West 1983). Grazing also reduces vegetation cover, which then promotes topsoil loss via acceleration of soil erosion ( $\mathrm{Li}$ et al. 2007). However, the extent to which topsoil resource depletions potentially caused by grazing-induced erosion might favor the germination and establishment of shrubs over grasses is largely unknown. Here, we address this knowledge gap and report results of a bioassay experiment quantifying grass and shrub germination and early seedling establishment on winnowed and non-winnowed surface soils.

Soil degradation by erosion has long been a pervasive concern in arid and semiarid ecosystems (Lal 2001; Schlesinger et al. 1990). While the detachment, transport, relocation of soil particles is a natural land surface process, it has been exacerbated by anthropogenic disturbances such as livestock grazing (Nearing et al. 2017). Furthermore, predicted increases in global aridity due to climate change (Berg et al. 2016; Cook et al. 2004) will intensify soil erosion and land degradation in these vulnerable ecosystems (Nearing et al. 2004). Aeolian and fluvial processes are the two primary drivers of soil erosion that can be coupled at different spatial and temporal scales in drylands
(Belnap et al. 2011; Okin et al. 2018). However, the combination of low moisture availability, strong seasonal winds, and sparse vegetation likely makes wind erosion more consequential than fluvial processes in many arid regions. Aeolian transport of soil particles affects the spatial distribution of resources in dryland ecosystems that, in turn, may differentially influence the recruitment of dryland plant functional groups (Alvarez et al. 2012; Armbrust and Retta 2000; Okin et al. 2018). Wind erosion following the grass cover reductions accompanying grazing has been documented to rapidly change both physical and chemical properties of surface soils by depleting fine and nutrient-rich soil particles, leaving behind coarser soils that are lower in nutrients (e.g., Li et al. 2007, 2008). Here, we sought to ascertain if this "winnowing" process, might differentially influence the establishment of contrasting grass and shrub functional groups.

Winnowing primarily affects the topsoil (e.g., Li et al. 2007, 2009). Accordingly, its influence on vegetation is ostensibly realized via its effects on the seed germination and early seedling growth phases of the plant life cycle, as adult plants could access water/ nutrients deeper in the soil as roots develop. Changes in surface soil physical properties (e.g., texture and structure) could alter soil temperature and moisture regimes, light penetration, air permeability, and mechanical resistance, all of which are important factors affecting seed germination, seedling emergence and early growth (e.g., Benvenuti 2003; Chachalis and Reddy 2000; El-Keblawy 2017). Seed traits (e.g., mass, morphology) will interact with these abiotic factors to further influence germination and emergence probabilities (Leishman et al. 2000; Saatkamp et al. 2019). The shrub and grass species used in our study have distinctly different seed traits (e.g., shrubs have much larger seed mass than grasses; Table 1), which may favor shrub recruitment on water- and nutrient-limited soils (Huang et al. 2016; MerinoMartín et al. 2017). These interactions between soil physical/chemical properties and seed characteristics may lead to different germination and early establishment potentials of contrasting plant functional groups on winnowed surfaces.

Within and between shrub and grass functional groups, species trait differences related to resource utilization may additionally influence the likelihood of their respective establishment on non-winnowed vs. winnowed soils. For example, $\mathrm{C}_{4}$ species typically have 
Table 1 Summary of functional attributes of targeted grass and shrub species

\begin{tabular}{|c|c|c|c|c|c|c|c|c|}
\hline Species & $\begin{array}{l}\text { Functional } \\
\text { group }\end{array}$ & Growthform & Family & Species code & $\begin{array}{l}\text { Photo- } \\
\text { synthetic } \\
\text { pathway }\end{array}$ & Leaf habit & $\mathrm{N}_{2}$-fixing & $\begin{array}{l}\text { Seed } \\
\text { mass }(\mathrm{mg} ; \\
\text { mean } \pm \mathrm{SD})\end{array}$ \\
\hline $\begin{array}{l}\text { Aristida purpurea } \\
\text { Nutt. }\end{array}$ & Grass & Stoloniferous & Poaceae & ARPU & $\mathrm{C}_{4}$ & Deciduous & No & $1.3 \pm 0.1$ \\
\hline $\begin{array}{l}\text { Bouteloua eriopoda } \\
\text { (Torr.) Torr. }\end{array}$ & Grass & Bunchgrass & Poaceae & BOER & $\mathrm{C}_{4}$ & Deciduous & No & $0.4 \pm 0.03$ \\
\hline $\begin{array}{l}\text { Sporobolus airoides } \\
\text { (Torr.) Torr. }\end{array}$ & Grass & Bunchgrass & Poaceae & SPAI & $\mathrm{C}_{4}$ & Deciduous & No & $0.2 \pm 0.04$ \\
\hline $\begin{array}{l}\text { Atriplex canescens } \\
\text { (Pursh) Nutt. }\end{array}$ & Shrub & Suffruticose & $\begin{array}{l}\text { Amaran- } \\
\text { thaceae }\end{array}$ & ATCA & $\mathrm{C}_{4}$ & $\begin{array}{l}\text { Semi-ever- } \\
\text { green }\end{array}$ & No & $28.0 \pm 4.4$ \\
\hline $\begin{array}{l}\text { Larrea tridentata } \\
\text { (DC.) Coville }\end{array}$ & Shrub & Fruticose & $\begin{array}{l}\text { Zygophyl- } \\
\text { laceae }\end{array}$ & LATR & $\mathrm{C}_{3}$ & Evergreen & No & $5.6 \pm 0.9$ \\
\hline $\begin{array}{l}\text { Prosopis glandu- } \\
\text { losa Torr. }\end{array}$ & Shrub & $\begin{array}{l}\text { Fruticose/ } \\
\text { arborescent }\end{array}$ & Fabaceae & PRGL & $\mathrm{C}_{3}$ & Deciduous & Yes & $36.9 \pm 1.9$ \\
\hline
\end{tabular}

higher water and nitrogen use efficiency than $\mathrm{C}_{3}$ plants in dry environments (Pearcy and Ehleringer 1984; Sage 2004). As a result, $\mathrm{C}_{4}$ plants may grow better on nutrient-depleted winnowed soils with low water/nutrient holding capacity than $\mathrm{C}_{3}$ plants. Similarly, species that host $\mathrm{N}_{2}$-fixing bacteria could perform better on nitrogendepleted soils than those lacking this trait (Monks et al. 2012; Zahran 1999). Plants with evergreen foliage can be more drought tolerant, have slower growth rates, lower resource requirements and more conservative nutrient cycling dynamics (Givnish 2002; Wright et al. 2004), so would ostensibly fare better on resource-depleted winnowed soils than deciduous plants. Here, we sought to determine the extent to which plants with these contrasting functional traits (photosynthetic pathway; leaf habit; $\mathrm{N}_{2}$-fixation potential) might differ with respect to germination and early seedling growth on non-winnowed and winnowed soils.

We hypothesized that if topsoil winnowing by wind erosion following vegetation loss differentially influences grass and shrub seed germination and seedling establishment to promote shrub recruitment over that of grass, then it could be a mechanism underlying the widely-observed shifts from grass to shrub dominance in grazed drylands. To test this hypothesis, we conducted a greenhouse bioassay experiment that monitored germination and seedling growth of arid-adapted grass and shrub species grown in topsoils obtained from non-winnowed and winnowed portions of a Chihuahuan Desert landscape. Our experiment was conducted in a controlled greenhouse setting, allowing for well-standardized conditions, and avoiding potentially confounding factors that may occur with field trials (e.g., spatial variation in soil properties, rainfall, arthropod and rodent herbivory, etc.). The results could shed light on how different functional groups (Table 1) perform on wind-eroded soils during the early establishment phase of their life cycle, and how this might be linked to grass-to-shrub transitions observed in wind-erodible arid grasslands.

\section{Materials and methods}

Soil sampling and characterization

Soils used in the bioassay experiment were collected at the Jornada Experimental Range (JER)/Jornada Basin Long-Term Ecological Research site in southwestern New Mexico, USA. In 1991, vegetation was removed from a 2-ha area ("scrape site"; UTM 13N 334,896 m E, 3,605,250 m N; Gillette and Chen 2001) within the basin floor geomorphic unit (Monger et al. 2006) where grasslands have historically given way to honey mesquite (Prosopis glandulosa Torr.) shrublands (Gibbens et al. 2005). Initially designed to 
monitor long-term wind erosion mechanisms by manually removing all vegetation (Gillette and Chen 2001), the scrape site is also a proxy for the extreme vegetation loss that would have accompanied the long-term overgrazing that occurred historically (dating back to the late 1800s) and is still on-going in some areas. The area downwind of the scrape site has been exposed to intensified aeolian processes (i.e., wind erosion), and has become dominated by bare soil and coppice dunes (nebkhas) forming around large honey mesquite shrubs. Li et al. (2007) have documented the significant soil winnowing effects that have occurred in near-surface (upper $5 \mathrm{~cm}$ ) soils. In this study, winnowed soils were obtained from a location (UTM 13N 334,954 m E, 3,605,282 $\mathrm{m} \mathrm{N}$ ) $20 \mathrm{~m}$ downwind of the scrape site (Fig. 1). These soils were collected with a flat trowel to a depth of $2 \mathrm{~cm}$ to ensure we were using soils that had been maximally impacted. Non-winnowed soils were collected with the flat trowel to a depth of $5 \mathrm{~cm}$ at a location $\sim 150 \mathrm{~m}$ away (UTM 13N 334,932 m E, $3,605,136 \mathrm{~m} \mathrm{~N}$; Fig. 1) along a transect oriented perpendicular to the prevailing winds (to minimize potentially confounding effects of using soils from upwind and downwind locations). The vegetation at the sampling site for non-winnowed soils was characterized by perennial grasses (primarily Aristida purpurea, Bouteloua eriopoda, and Sporobolus spp.) and shrubs (P. glandulosa, Atriplex canescens, and Yucca elata). Field-collected soils were transported to the University of Arizona campus, spread on a greenhouse bench, allowed to air dry and then sieved ( $5 \mathrm{~mm}$ mesh).

Soils were classified according to the USDA guidelines (USDA Soil Science Division Staff 2017). The texture was determined by the hydrometer method. Soil $\mathrm{pH}$ and electrical conductivity (EC) were measured in 1:1 soil to water suspension (volume to volume; deionized water). Exchangeable cations, including $\mathrm{K}^{+}, \mathrm{Na}^{+}, \mathrm{Ca}^{2+}$, and $\mathrm{Mg}^{2+}$ were analyzed in ammonium acetate solution buffered to $\mathrm{pH} 8.5$ using an inductively coupled plasma optical emission spectrometry (ICP-OES, iCAP7200, Thermo-Fisher, Freemont, CA, USA). Soil $\mathrm{NO}_{3}{ }^{-}$was extracted with $2 \mathrm{M} \mathrm{KCl}$ and analyzed by reduction to nitrite $\left(\mathrm{NO}_{2}^{-}\right)$via cadmium reduction. Soil $\mathrm{PO}_{4}{ }^{3-}$ was extracted using $0.5 \mathrm{M} \mathrm{NaHCO}_{3}$ adjusted to $\mathrm{pH}$ 8.5. Both $\mathrm{NO}_{3}{ }^{-}$and $\mathrm{PO}_{4}{ }^{3-}$ were measured with a continuous flow analyzer $\left(\mathrm{San}^{++}\right.$, Skalar CFA, Skalar Analytical BV, Breda, the Netherlands). Cation exchange capacity (CEC) was estimated as the sum of exchangeable $\mathrm{K}^{+}, \mathrm{Na}^{+}, \mathrm{Ca}^{2+}$, and $\mathrm{Mg}^{2+}$. Exchangeable sodium percentage (ESP) was calculated as ESP $(\%)=\left(\right.$ exchangeable $\mathrm{Na}^{+}$/ $\mathrm{CEC}) \times 100$. Soil total $\mathrm{C}$ and total $\mathrm{N}$ were measured with a C\&N analyzer (LECO TruSpec, LECO Corporation, St. Joseph, MI, USA). Mean values for a given soil variable are based on $n=10$ replicates.

To generate soil water retention curve for each soil type, air-dried soil samples were sieved through $2 \mathrm{~mm}$ mesh and rewetted with deionized water to create a
Fig. 1 Non-winnowed and winnowed soil sampling sites at the Jornada Experimental Range (JER) "scrape site" (Gillette and Chen 2001), Las Cruces, New Mexico, USA

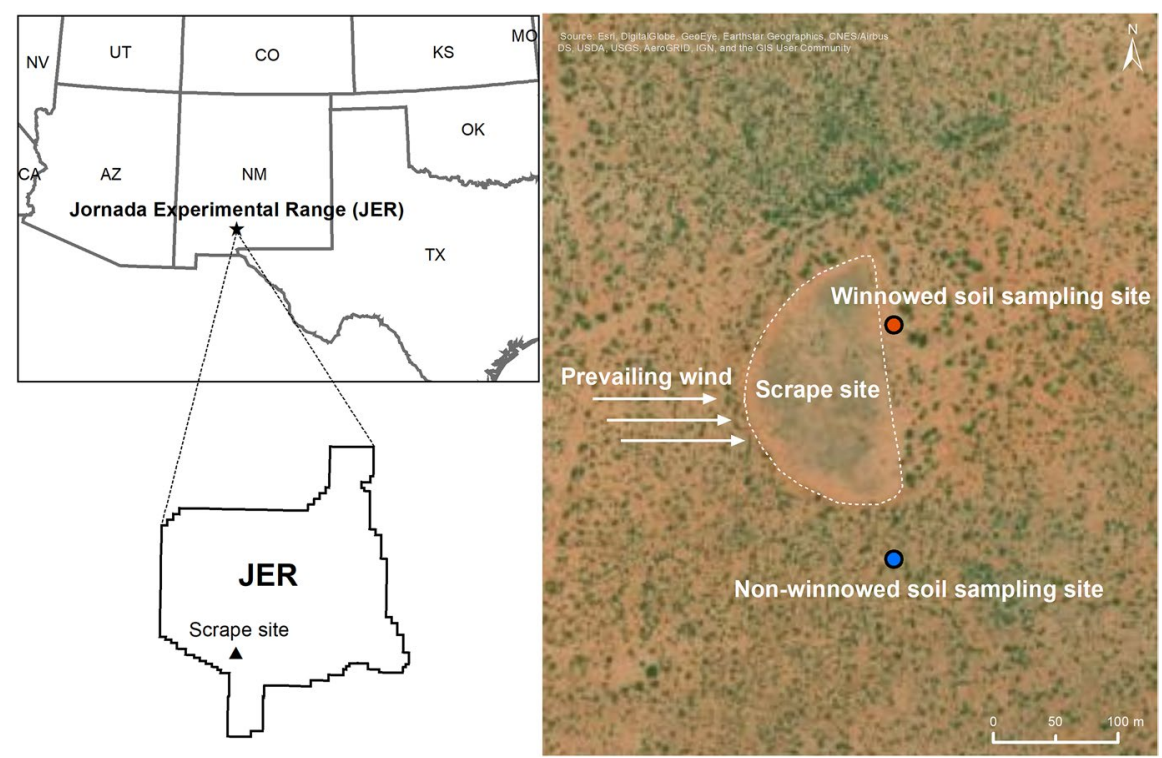


range of water contents (ranging from low [air-dried] to saturated in $0.025 \mathrm{~g} \mathrm{~g}^{-1}$ intervals; $n=6$ per soil water content) per Campbell et al. (2007). Water potentials of these soil samples were then determined with a dewpoint water potential meter (WP4, Decagon, Pullman, WA, USA). Following water potential measurements, soil samples were oven-dried at $105{ }^{\circ} \mathrm{C}$ for $24 \mathrm{~h}$ and weighed to derive gravimetric water contents. Volumetric water contents $\left(\mathrm{cm}^{3} \mathrm{~cm}^{-3}\right)$ were then calculated by multiplying gravimetric water contents by the bulk density $\left(\mathrm{g} \mathrm{cm}^{-3}\right)$ of the respective soil type measured at soil sampling sites using the core method (Grossman and Reinsch 2002).

\section{Plant functional groups}

Three grass and three shrub species with different growth forms were targeted in this study (Table 1). All are native and common in Chihuahuan Desert grasslands and represent a broad range of plant functional groups in semiarid and arid regions globally. Grass species included two $\mathrm{C}_{4}$ perennial bunchgrasses, Aristida purpurea Nutt. and Sporobolus airoides (Torr.) Torr., and a perennial $\mathrm{C}_{4}$ stoloniferous grass Bouteloua eriopoda (Torr.) Torr., the historically dominant grass in Chihuahuan Desert grasslands (Gibbens et al. 2005). The three shrub species were Prosopis glandulosa Torr., a deciduous $\mathrm{C}_{3}$ species with $\mathrm{N}_{2}$-fixation potential; Larrea tridentata DC. (Coville), an evergreen $\mathrm{C}_{3}$ true xerophyte; and Atriplex canescens (Pursh) Nutt., a semi-evergreen, suffruticose $\mathrm{C}_{4}$ species.

\section{Greenhouse experiments}

Pot trials were conducted in a greenhouse on the University of Arizona campus in Tucson, AZ, USA. Seeds of A. purpurea, S. airoides, L. tridentata, and A. canescens were obtained from a regional seed supplier (Plants of the Southwest, Albuquerque, NM, USA). Seeds of B. eriopoda were obtained from the Los Lunas Plant Materials Center, Natural Resources Conservation Service, USDA. Seeds of $P$. glandulosa were collected from the JER in 2010 and stored in a sealed glass jar in the dark. The viability of all seed lots was determined prior to the experiment, with shrubs and grasses having average germinabilities of $50 \%$ and $81 \%$, respectively (Shereen Nadoum, unpublished data). Prior to sowing, P. glandulosa seeds were scarified by scratching the hard seed coat with a metal file to overcome seed coat-imposed dormancy and allow water imbibition; no pre-treatments were required for seeds of the other species. For each species, seeds were qualitatively selected for uniformity of size.

Germination on non-winnowed and winnowed soils

This experiment sought to investigate the germination of target grass and shrub species on non-winnowed and winnowed soils and was conducted in April 2018. Small plastic pots $(8 \mathrm{~cm}$ width $\times 8 \mathrm{~cm}$ length $\times 6 \mathrm{~cm}$ height) were filled with either non-winnowed or winnowed soil $(n=10$ per species per soil type for a total of 120 pots). Pots had holes on bottoms to allow drainage of excess water. Ten seeds per species were sown $\sim 1 \mathrm{~cm}$ below the soil surface in each pot for all species. Soils were brought to field water capacity on the day of sowing and moistened with the same amount of water daily thereafter. Seed germination, defined as cotyledon emergence, was recorded daily. The experiment ceased when zero cotyledon emergence was recorded in all pots for five consecutive days. Germinability $(G ; \%)$ was calculated as:

$G=\frac{\sum n_{i}}{N} \times 100$

where $n_{i}$ is the number of seeds germinated on day $i ; N$ is the total number of sown seeds (10 per pot).

Mean germination time ( $T$; day) was calculated as (Ranal et al. 2009):

$T=\frac{\sum t_{i} \times n_{i}}{\sum n_{i}}$

where $t_{i}$ is the number of days after sowing, $n_{i}$ is the number of seeds germinated on day $i$.

Seedling growth on non-winnowed and winnowed soils

This experiment was aimed at quantifying seedling growth on non-winnowed and winnowed soils. Two separate trials of the same experiment were carried out: one in 2018 (04 March - 04 April, 31 days; hereafter shorter-term trial) and the other in 2019 (01 January - 17 March, 76 days; hereafter longer-term 
trial). The greenhouse received full sun exposure and contained no supplemental lighting. The daytime temperature maximum was set at $32{ }^{\circ} \mathrm{C}$ and the nighttime minimum was $24{ }^{\circ} \mathrm{C}$, which is a favorable temperature range for the germination and growth of the species in our experiment (Khan and Gulzar 2003; Young and Young 1992).

During each experimental trial, plants were grown in $26.5 \mathrm{~cm}$ tall $\times 3.15 \mathrm{~cm}$ diameter "Cone-tainers" (Stuewe and Sons, Inc., Corvallis, OR, USA). Pots $(n=12$ per species per soil type for a total of 144 pots) had a $7.5 \mathrm{~cm}$ base layer of mineral wool (to prevent soil from falling through drainage holes) overlain by $14 \mathrm{~cm}$ of play sand. The sandy base layer was then topped (upper $5 \mathrm{~cm}$ ) with either non-winnowed or winnowed soil. Pots were spatially randomized on the greenhouse bench. The pots were brought to field capacity on the day of sowing and kept moist by adding the same amount of water per pot daily thereafter. At the end of the experiment, plant height and number of leaves were recorded. Aboveground material was separated into leaf and stem categories (for shrubs) and soils were gently washed away from roots. Plant materials were oven-dried at $65{ }^{\circ} \mathrm{C}$ for $48 \mathrm{~h}$ and weighed.

\section{Statistical analyses}

All analyses were performed with $\mathrm{R}$ version 4.0.0 (R Core Team 2020). The Student's $t$-test was used for analyzing differences in soil properties, germination indices, and plant morphological characteristics (e.g., plant height, number of leaves, above- and belowground biomass) between soil types within a species. One-way ANOVA was used for analyzing differences in germination indices and morphological characteristics among species. Tukey's HSD test was used for multiple comparisons. Factorial ANOVA was used for testing the effects of plant functional group (grass vs. shrub), soil type (non-winnowed vs. winnowed), and their interactions on morphological characteristics in shorter- and longer-term trials separately. Soil water retention curves were derived by fitting soil water potential (SWP) and volumetric soil water content (VWC) data using a power function (VWC $=\mathrm{a} \times \mathrm{SWP}^{\mathrm{b}}$; Campbell and Shiozawa 1992). Additionally, time-to-event analysis (i.e., survival analysis) was used to assess the temporal dynamics of seed germination. Following McNair et al. (2012), germination probability was estimated using nonparametric Kaplan-Meier method with the 'survfit' function from the 'survival' package in $\mathrm{R}$ (Therneau 2015). The G- $\rho$ family of tests were used to compare the survivor functions of seeds grown on different soil types (using the 'survdiff' function from the R 'survival' package).

\section{Results}

\section{Soil properties}

The non-winnowed soil had significantly higher silt and significantly lower sand content than the winnowed soil, while clay content was equivocal (Table 2). As a result, the non-winnowed soil was classified as loamy sand whereas the winnowed soil was sand. The non-winnowed soil had significantly higher $\mathrm{pH}, \mathrm{K}^{+}, \mathrm{Ca}^{2+}, \mathrm{CEC}$, and total $\mathrm{C}$ and $\mathrm{N}$ than the winnowed soil; their $\mathrm{Na}^{+}, \mathrm{Mg}^{2+}, \mathrm{NO}_{3}{ }^{-}, \mathrm{PO}^{3-}$, and ESP composition were statistically comparable.

Volumetric water content at field capacity was higher for the non-winnowed soil $\left(0.132 \mathrm{~cm}^{3} \mathrm{~cm}^{-3}\right)$ than the winnowed soil $\left(0.118 \mathrm{~cm}^{3} \mathrm{~cm}^{-3}\right)$ (Fig. 2, inset). However, water in the non-winnowed soil was bound at lower water potentials than that of water in the winnowed soil at a given water content, particularly towards the dry range of soil moisture (Fig. 2).

\section{Germination on non-winnowed and winnowed soils}

Within species, mean germination time ( $T$; day) and germinability $(G ; \%)$ were statistically comparable on non-winnowed and winnowed soils (Table 3). Mean germination time averaged across soil types $\left(T_{\text {avg }}\right)$ of P. glandulosa $(7.0 \pm 2.0$ day; mean $\pm \mathrm{SD}$; Table 3$)$ was significantly shorter than those of $A$. purpurea and $S$. airoides (grasses) and L. tridentata (shrub). The grass species B. eriopoda and A. purpurea were slightly slower to germinate, with $T_{\text {avg }}$ of $8.1 \pm 2.1$ and $10.3 \pm 3.9$ day, respectively, which were still significantly shorter than $S$. airoides $(13.5 \pm 4.0$ day) and L. tridentata $(14.5 \pm 3.9$ day). Average germinability across soil types $\left(G_{\mathrm{avg}}\right)$ of $A$. purpurea and P. glandulosa $(91.0 \pm 17.1$ and $90.0 \pm 11.2 \%$, respectively; Table 3) was significantly greater than the other species. $G_{\text {avg }}$ of B. eriopoda $(67.0 \pm 15.3 \%)$ was significantly greater than that of $S$. airoides, A. canescens, 
Table 2 Physical and chemical properties (mean $\pm \mathrm{SD}$ ) of nonwinnowed and winnowed soils

“*” indicates significant (Student's $t$-test, $p<0.05$ ) differences between soil types

\begin{tabular}{|c|c|c|}
\hline Soil variable & Non-winnowed & Winnowed \\
\hline Sand $(\%)$ & $86.8 \pm 1.1$ & $90.4 \pm 1.1 *$ \\
\hline Silt $(\%)$ & $6.0 \pm 1.4^{*}$ & $3.4 \pm 0.9$ \\
\hline Clay $(\%)$ & $7.2 \pm 1.1$ & $6.2 \pm 0.4$ \\
\hline Soil texture & Loamy sand & Sand \\
\hline $\mathrm{pH}$ & $8.1 \pm 0.1^{*}$ & $7.8 \pm 0.3$ \\
\hline Electrical conductivity $\left(\mathrm{EC} ; \mathrm{dS} \mathrm{m}^{-1}\right)$ & $0.099 \pm 0.013$ & $0.087 \pm 0.018$ \\
\hline $\mathrm{K}^{+}\left(\mathrm{mg} \mathrm{kg}^{-1}\right)$ & $191.0 \pm 13.7^{*}$ & $137.0 \pm 11.6$ \\
\hline $\mathrm{Na}^{+}\left(\mathrm{mg} \mathrm{kg}^{-1}\right)$ & $7.3 \pm 4.3$ & $8.2 \pm 3.9$ \\
\hline $\mathrm{Ca}^{2+}\left(\mathrm{mg} \mathrm{kg}^{-1}\right)$ & $1019.0 \pm 162.3 *$ & $799.0 \pm 101.4$ \\
\hline $\mathrm{Mg}^{2+}\left(\mathrm{mg} \mathrm{kg}^{-1}\right)$ & $109.4 \pm 12.3$ & $115.1 \pm 16.9$ \\
\hline $\mathrm{NO}_{3}^{-}\left(\mathrm{mg} \mathrm{kg}^{-1}\right)$ & $3.1 \pm 1.0$ & $4.1 \pm 1.8$ \\
\hline $\mathrm{PO}_{4}{ }^{3-}\left(\mathrm{mg} \mathrm{kg}^{-1}\right)$ & $10.8 \pm 2.9$ & $12.9 \pm 4.0$ \\
\hline Exchangeable sodium percentage (ESP; \%) & $0.5 \pm 0.3$ & $0.7 \pm 0.4$ \\
\hline Cation exchange capacity (CEC; meq $100 \mathrm{~g}^{-1}$ ) & $6.5 \pm 0.9 *$ & $5.3 \pm 0.7$ \\
\hline Total C (\%) & $0.202 \pm 0.037 *$ & $0.155 \pm 0.035$ \\
\hline Total N (\%) & $0.028 \pm 0.019 *$ & $0.025 \pm 0.021$ \\
\hline
\end{tabular}

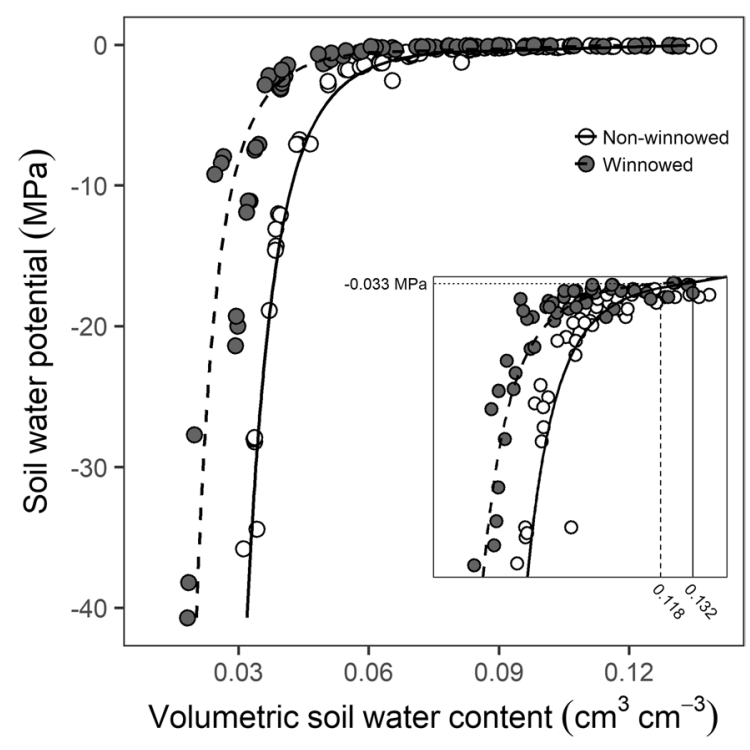

Fig. 2 Soil water retention curves for non-winnowed and winnowed soils. Inset: volumetric soil water content $\left(\mathrm{cm}^{3} \mathrm{~cm}^{-3}\right)$ at field capacity (-0.033 MPa)

and $L$. tridentata. The semi-evergreen shrub A. canescens had the lowest germinability of all species $\left(G_{\text {avg }}=13.0 \pm 13.0 \%\right)$. Survival analyses showed that there were no significant differences in seed germination probability on the two soil types, with one exception: germination of $A$. purpurea was higher $(p<0.001)$ on non-winnowed soils (Fig. 3).

Seedling growth on non-winnowed and winnowed soils

Results of factorial ANOVA showed that with the exception of height in the longer-term trial, plant functional group significantly affected all morphological and growth characteristics. Soil type only significantly affected root:shoot ratio, number of leaves, and plant height in the shorter-term trial (Table 4). Aboveground growth of the three grasses and the A. canescens shrub was significantly greater on winnowed soils in the shorter-term trial, but only for the A. purpurea grass in the longer-term trial (Fig. $4 \mathrm{a}, \mathrm{c}$ ). With the exception of $A$. purpurea and $P$. glandulosa in the shorter-term trial, belowground biomass was comparable on the two soil types for all species in both trials (Fig. 4b, d). Shrubs produced more biomass than grasses, particularly in $P$. glandulosa, which had significantly greater above- and belowground biomass (pooled across soil types) than all grass species in both trials (data not shown). With the exception of A. purpurea and S. airoides, root:shoot (R:S) ratios were significantly greater on non-winnowed soils in the shorter-term trial (Fig. 5a). However, in the longer-term trial, $\mathrm{R}: \mathrm{S}$ ratios were comparable among soil types; the lone exception was $L$. tridentata, where 
Table 3 Germination indices (mean \pm SD) of grasses and shrubs growing on non-winnowed soils, winnowed soils, and averaged across the two soil types.

\begin{tabular}{|c|c|c|c|c|c|c|c|}
\hline \multirow{2}{*}{$\begin{array}{l}\text { Func- } \\
\text { tional } \\
\text { group }\end{array}$} & \multirow[t]{2}{*}{ Species } & \multicolumn{3}{|c|}{ Mean germination time ( $T$; day) } & \multicolumn{3}{|c|}{ Germinability $(G ; \%)$} \\
\hline & & Non-winnowed & Winnowed & Average & Non-winnowed & Winnowed & Average \\
\hline \multirow[t]{3}{*}{ Grass } & A. purpurea & $9.0 \pm 3.0$ & $11.6 \pm 4.5$ & $10.3 \pm 3.9 b$ & $96.0 \pm 9.7$ & $86.0 \pm 21.7$ & $91.0 \pm 17.1 \mathrm{~d}$ \\
\hline & B. eriopoda & $8.3 \pm 2.1$ & $8.0 \pm 2.2$ & $8.1 \pm 2.1 \mathrm{ab}$ & $65.0 \pm 19.0$ & $69.0 \pm 11.0$ & $67.0 \pm 15.3 \mathrm{c}$ \\
\hline & S. airoides & $13.5 \pm 4.5$ & $13.4 \pm 3.5$ & $13.5 \pm 4.0 \mathrm{~cd}$ & $41.0 \pm 17.3$ & $35.0 \pm 19.6$ & $38.0 \pm 18.2 b$ \\
\hline \multirow[t]{3}{*}{ Shrub } & A. canescens & $10.0 \pm 1.0$ & $10.1 \pm 3.9$ & $10.0 \pm 2.7 \mathrm{abc}$ & $15.0 \pm 14.3$ & $11.0 \pm 12.0$ & $13.0 \pm 13.0 \mathrm{a}$ \\
\hline & L. tridentata & $14.8 \pm 3.4$ & $14.2 \pm 4.5$ & $14.5 \pm 3.9 \mathrm{~d}$ & $44.0 \pm 14.3$ & $40.0 \pm 15.6$ & $42.0 \pm 14.7 b$ \\
\hline & P. glandulosa & $7.7 \pm 1.7$ & $6.4 \pm 2.0$ & $7.0 \pm 2.0 \mathrm{a}$ & $90.0 \pm 11.5$ & $90.0 \pm 11.5$ & $90.0 \pm 11.2 \mathrm{~d}$ \\
\hline
\end{tabular}

There was no significant (Student's $t$-test, $p>0.05)$ difference in mean germination time $(T)$ or germinability $(G)$ between soil types for any species. Different letters indicate significant differences among species (one-way ANOVA, $p<0.05$ ) in $T$ or $G$ averaged across soil types.
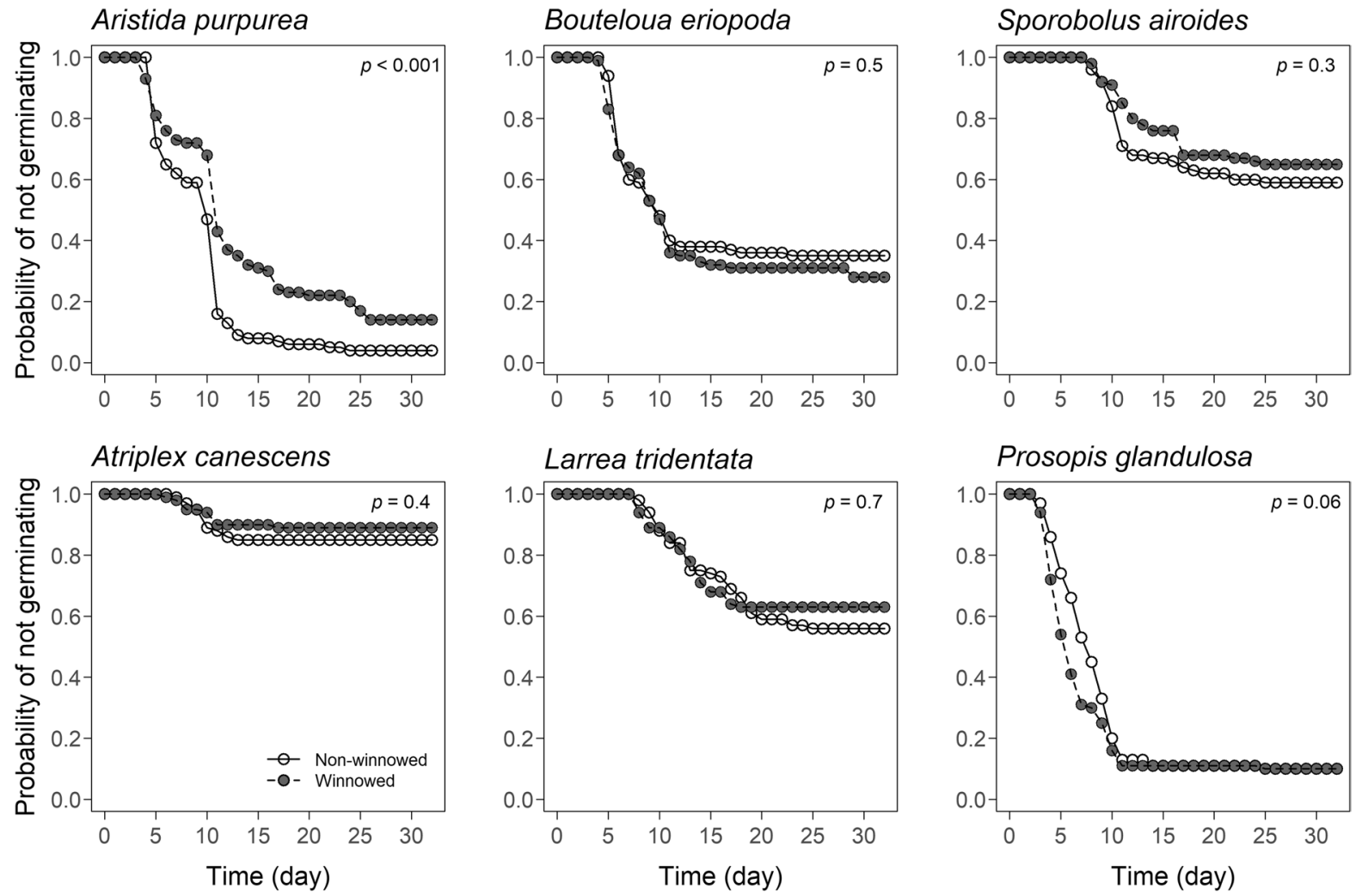

Fig. 3 Kaplan-Meier estimates of survivor functions for grasses and shrubs (Table 1) growing on non-winnowed and winnowed soils

R:S ratio was significantly greater on non-winnowed soils (Fig. 5b). Grasses typically had higher R:S ratios than shrubs (Fig. 5; Table 4). Among grasses, A. purpurea had the greatest $\mathrm{R}: \mathrm{S}$ ratio when pooled across soil types (mean $\pm \mathrm{SD}=1.4 \pm 0.5$ [shorter-term trial] and 3.1 \pm 1.7 [longer-term trial]; data not shown).

The number of leaves per plant was generally comparable on non-winnowed and winnowed soils in all species in both trials. The exceptions were $B$. 
Table 4 Results ( $F$ values) of factorial ANOVA examining the effects of plant functional group (grass vs. shrub), soil (non-winnowed vs. winnowed), and their interaction on aboveground biomass, belowground biomass, total biomass, root:shoot ratio, number of leaves, and height

\begin{tabular}{|c|c|c|c|c|c|c|c|}
\hline Factor & df & $\begin{array}{l}\text { Above- } \\
\text { ground } \\
\text { biomass }\end{array}$ & $\begin{array}{l}\text { Below- } \\
\text { ground } \\
\text { biomass }\end{array}$ & Total biomass & Root:shoot ratio & Number of leaves & Height \\
\hline \multicolumn{8}{|l|}{ Shorter-term trial } \\
\hline Plant functional type & 1 & $87.80^{* * *}$ & $64.32^{* * * *}$ & $80.94^{* * *}$ & $9.85^{* *}$ & $181.86^{* * *}$ & $107.65^{* * * *}$ \\
\hline Soil & 1 & 0.48 & 1.31 & 0.01 & $6.78^{*}$ & $9.92^{* *}$ & $20.53^{* * *}$ \\
\hline Plant functional type $\times$ Soil & 1 & 0.09 & 2.13 & 0.19 & 0.91 & 3.56 & 2.76 \\
\hline \multicolumn{8}{|l|}{ Longer-term trial } \\
\hline Plant functional type & 1 & $147.50^{* * *}$ & $54.19^{* * * *}$ & $106.21^{* * *}$ & $20.65^{* * *}$ & $41.05^{* * *}$ & 0.02 \\
\hline Soil & 1 & 2.93 & 2.09 & 2.84 & 0.01 & 1.54 & 2.59 \\
\hline Plant functional type $\times$ Soil & 1 & 0.46 & 1.07 & 0.06 & 1.19 & 0.02 & 0.12 \\
\hline
\end{tabular}

“*” indicates $p<0.05$, “**” indicates $p<0.01$, “***” indicates $p<0.001 ; \mathrm{df}=$ degree of freedom

Fig. 4 Mean $( \pm S D)$ aboveground $(\mathbf{a}, \mathbf{c})$ and belowground (b, d) biomasses of grasses and shrubs growing on non-winnowed and winnowed soils in shorter-term (2018; 31 days) and longerterm (2019; 76 days) trials. A Student's $t$-test was used for testing the difference between soil types. "*" indicates significant $(p<0.05)$ difference. Species codes: ARPU $=$ Aristida purpurea $\mathrm{BOER}=$ Bouteloua erio poda, $\mathrm{SPAI}=$ Sporobolus airoides, $\mathrm{ATCA}=$ Atriplex canescens, $\mathrm{LATR}=$ Lar rea tridentata, and PRGL $=$ Prosopis gland $u$ losa

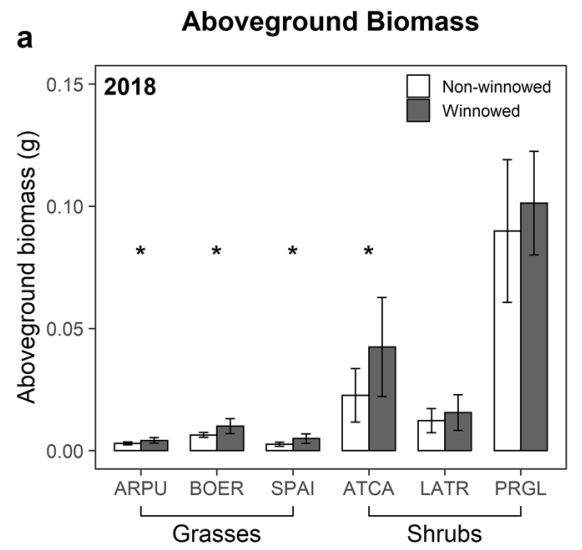

C

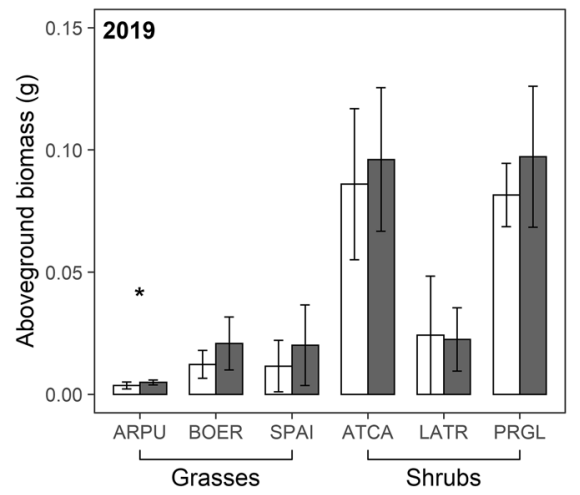

b

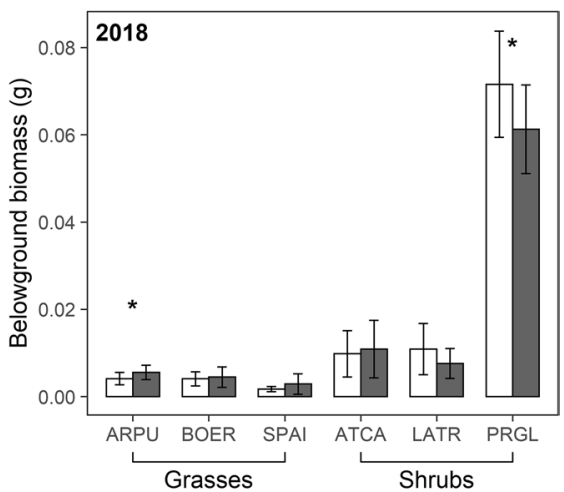

d

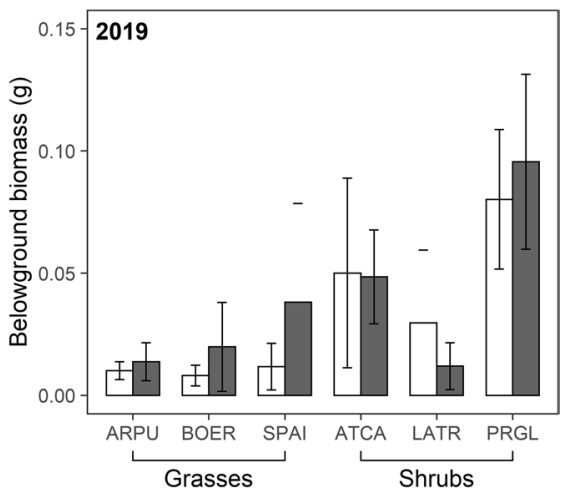

eriopoda and $P$. glandulosa which produced more leaves on winnowed soils in the shorter-term trial (Fig. 6a). Plant height was significantly higher on winnowed soils for B. eriopoda, S. airoides, A. canescens, and $P$. glandulosa in the shorter-term trial, and for $S$. airoides and A. canescens in the longer-term trial (Fig. 6b, d).

Leaf:stem (L:S) biomass ratios varied among shrub species but were not significantly different on non-winnowed and winnowed soils in either trial 


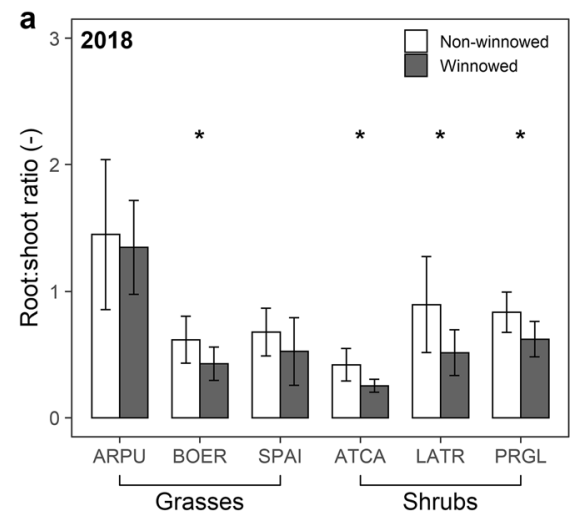

Fig. 5 Root:shoot ratios (mean \pm SD) of grasses and shrubs growing on non-winnowed and winnowed soils in shorter-term (2018; 31 days) and longer-term (2019; 76 days) trials. A Student's $t$-test was used for testing the difference between soil

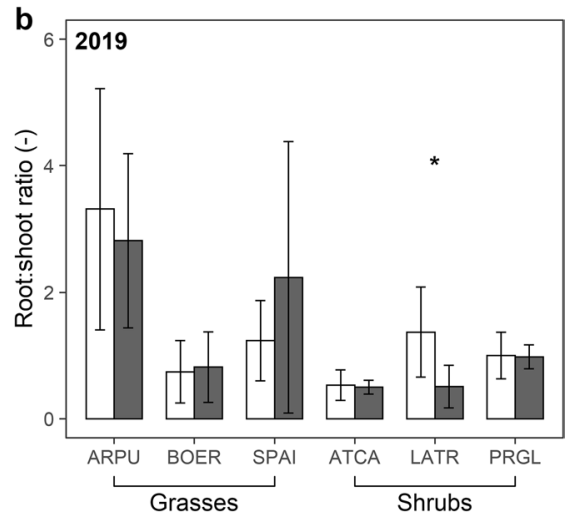

types. "** indicates significant $(p<0.05)$ difference. Species codes: $\mathrm{ARPU}=$ Aristida purpurea, $\mathrm{BOER}=$ Bouteloua eriop oda, $\mathrm{SPAI}=$ Sporobolus airoides, ATCA =Atriplex canescens, $\mathrm{LATR}=$ Larrea tridentat , and $\mathrm{PRGL}=$ Prosopis glandulosa
Fig. 6 Mean $( \pm S D)$ number of leaves $(\mathbf{a}, \mathbf{c})$ and plant height $(\mathbf{b}, \mathbf{d})$ of grasses and shrubs growing on nonwinnowed and winnowed soils in shorter-term (2018; 31 days) and longer-term (2019; 76 days) trials. A Student's $t$-test was used for testing the difference between soil types. "** indicates significant $(p<0.05)$ difference. Species codes: ARPU $=$ Aristida purpurea, $\mathrm{BOER}=$ Bouteloua erio poda, $\mathrm{SPAI}=$ Sporobolus airoides, $\mathrm{ATCA}=$ Atriplex canescens, $\mathrm{LATR}=$ Larrea tridentata, and PRGL = Prosopis gland $u$ losa

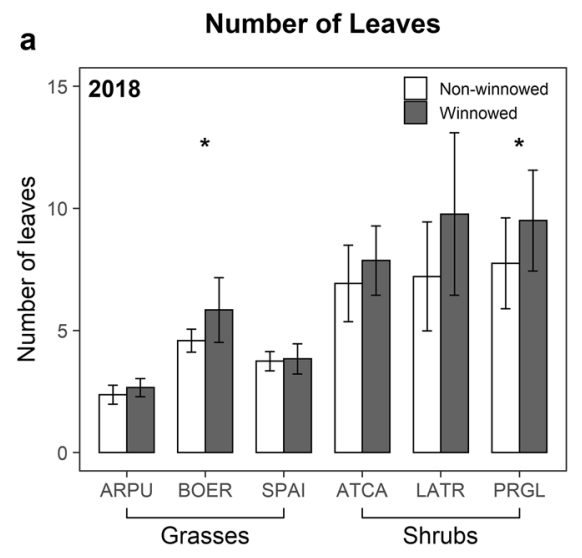

b Plant Height

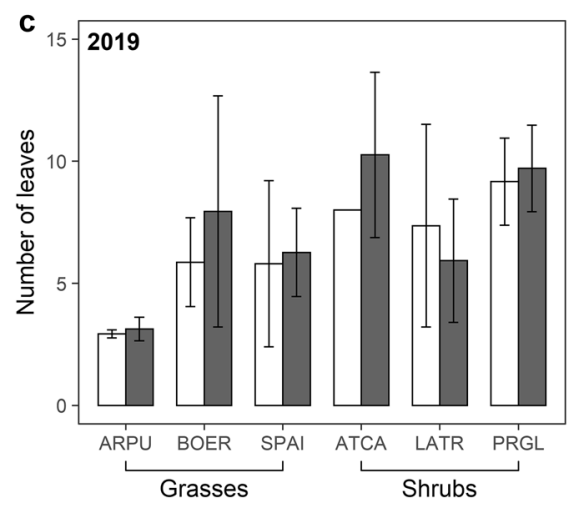

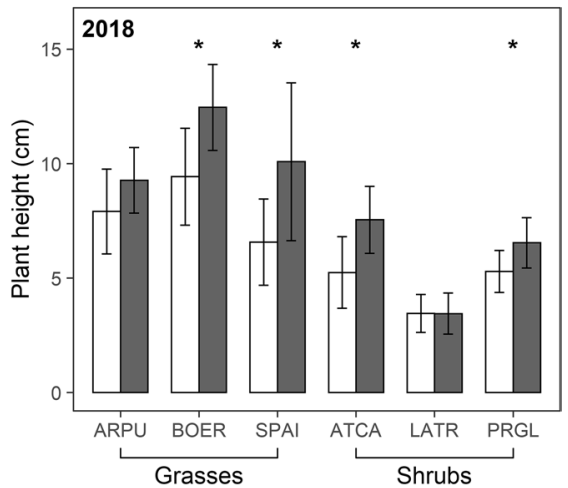

d

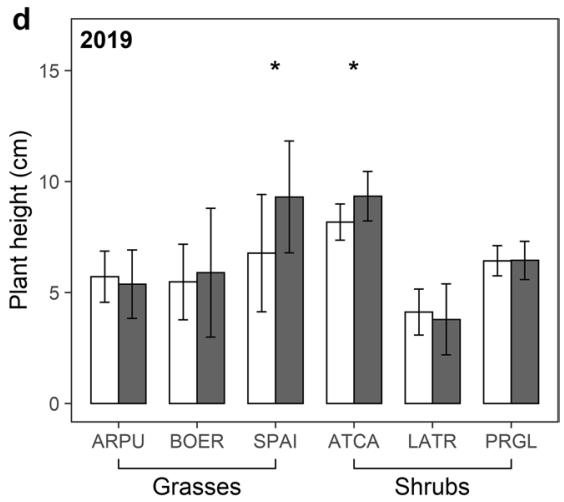

(Fig. 7a, b). The L:S ratios averaged across soil types were lowest in P. glandulosa $(1.2 \pm 0.4$ and $0.7 \pm 0.2$ in shorter- and longer-term trials, respectively; mean $\pm \mathrm{SD})$, highest in L. tridentata $(5.3 \pm 1.6$ and 


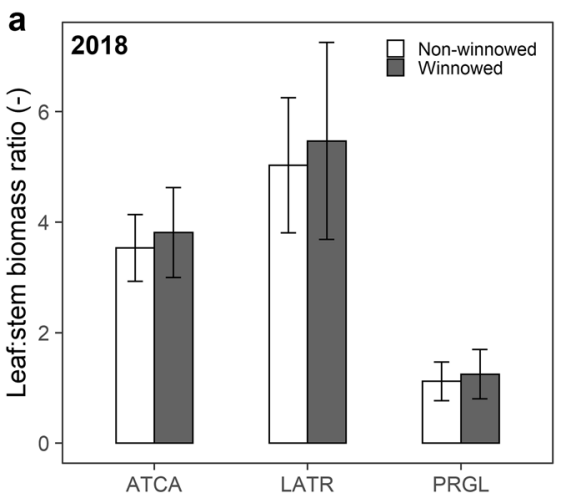

Fig. 7 Leaf:stem biomass ratios (mean \pm SD) of shrub species growing on non-winnowed and winnowed soils in shorterterm (2018; 31 days) and longer-term (2019; 76 days) trials. A

$2.3 \pm 0.9)$ and intermediate in A. canescens $(3.7 \pm 0.7$ and $1.8 \pm 0.4)(p<0.05$; data not shown $)$.

\section{Discussion}

Aeolian processes modify topsoil physical and chemical properties in dryland ecosystems (e.g., Li et al. 2007), and potentially impact vegetation growth and plant community dynamics (Alvarez et al. 2012). Here, we aimed to determine if the effects of soil winnowing might favor shrub recruitment over grasses, and hence contribute to the grassland-to-shrubland transitions that have occurred in many arid regions.

Our results showing that winnowed soils were coarser in texture and lower in nutrient content than non-winnowed soils (Table 2) are consistent with the findings of others (Alvarez et al. 2012; Li et al. 2007, 2008). We hypothesized that such differences would modify soil micro-environmental conditions (e.g., soil moisture, temperature, aeration) to differentially influence seed germination and seedling growth of targeted grasses and shrubs. However, our controlled-environment experiment indicated that for each of the grass and shrub species used in our trial, germinability and mean germination time on winnowed soils were comparable to that occurring on non-winnowed soils (Table 3). Survival analysis also indicated that with the exception of A. purpurea, all species had similar temporal patterns of germination on non-winnowed and winnowed soils. The lack of a winnowing effect on germination seen in

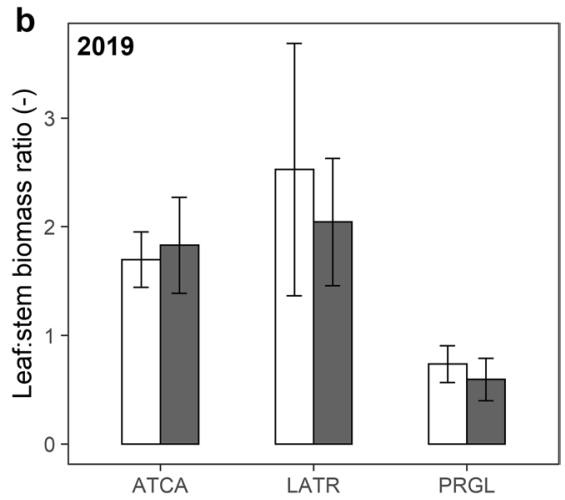

Student's $t$-test was used for testing the difference between soil types. Species codes: ATCA $=$ Atriplex canescens, $\mathrm{LATR}=$ Lar rea tridentata , and $\mathrm{PRGL}=$ Prosopis glandulosa

five of the six species in this study suggests that aeolianinduced differences in soil surface properties per se do not differentially influence grass vs. shrub germination under well-watered conditions.

Our controlled-environment experiment was narrowly focused on germination/early seedling establishment and did not account for other factors that are likely influencing plant recruitment on winnowed vs. non-winnowed sites. Wind erosion can, for example, deplete the soil seed bank and reduce the number of propagules available to germinate (Alvarez et al. 2012), ostensibly by blowing away newly dispersed seeds and those in the near-surface soil seed bank. This would be particularly true for smaller/ lighter grass seeds than for larger/heavier shrub seeds (Table 1$)$. In the shrub category, A. canescens and $L$. tridentata seeds are likely more amenable to wind dispersal than $P$. glandulosa seeds due to their morphological attributes (e.g., A. canescens is 'winged'). This would provide an advantage for $P$. glandulosa as its seeds, dispersed primarily via ungulate ingestion/ excretion (Brown and Archer 1987) and cacheing by rodents (Reynolds and Glendening 1949), would be more likely to persist upon arrival on wind-eroded soils. Aeolian redistribution of soil may also influence seed burial and hence germination and establishment (e.g., Traba et al. 2004; Merino-Martín et al. 2017). Burial may be deeper and quicker on sandy soils than on fine-textured clay soils, and protect seeds from predation, desiccation, and other biotic/abiotic stresses (Benvenuti 2007). On the other 
hand, seedling emergence may be inhibited if seeds are buried too deeply. This would be especially so for small-seeded grass species with limited seed reserves (Leishman et al. 2000). Moreover, coarser (i.e., winnowed) soils may capture and retain more large seeds than fine soils (Chambers et al. 1991). This could potentially increase the number of shrub seeds on winnowed sites and hence opportunities for recruitment. In our experiment, even without accounting for these other aeolian effects, the $P$. glandulosa shrub was the first to emerge, had the shortest mean germination time, and highest germinability (Table 3). Accordingly, the combined effects of seedbank depletion by wind erosion (Alvarez et al. 2012), potential capture of $P$. glandulosa seeds on winnowed soils as discussed above, and superior performance of $P$. glandulosa relative to A. canescens and L. tridentata in our germination/establishment trials suggest a biophysical mechanism by which $P$. glandulosa, and not the other two shrub species, has increased in abundance/cover on the basin floor geomorphic unit.

We hypothesized that seedling growth would be enhanced on non-winnowed soils relative to that on winnowed soils owing to the changes in soil physical and chemical properties accompanying winnowing. However, our results did not support this hypothesis: most species generated comparable to greater aboveand belowground biomass (Fig. 4), lower root:shoot ratio (Fig. 5), and were taller (Fig. 6) on winnowed soils than on non-winnowed soils. Accounting for this counter-intuitive outcome is problematic. Given that the winnowed soil generally had lower nutrient contents than the non-winnowed soil and the levels of two important macronutrients ( $\mathrm{N}$ and $\mathrm{P}$ ) were comparable (Table 2), soil nutrient levels cannot be invoked to account for the observed differences in plant growth. A water availability explanation seems likely. Soil texture and structure largely determine its matric potential, a critical component of soil water potential with respect to plants access to soil moisture (Jones 2007). The winnowed soil in this study was coarser in texture (Table 2), and thereby had higher (less negative) water potential than non-winnowed soils at a given moisture content, particularly under conditions of low soil water content (Fig. 2). This indicates that winnowed soils may have greater water 'availability' to plants. Though plants were wellwatered in our experiment, relatively dry conditions may have developed between watering events. The plants on winnowed soils may have benefitted from greater water availability during these intermittent dry periods. In natural conditions, the texture-related water potential differences experienced by seedlings on non-winnowed and winnowed soils would ostensibly be substantially greater than those occurring in our greenhouse study. Since moisture dry-down rates are rapid and intervals between precipitation events can be long in drylands (Fravolini et al. 2005), moisture differences between soil types could pronounced for extended periods of time, with consequential influences on plant growth. Further greenhouse/field studies manipulating soil moisture on winnowed and non-winnowed soils (particularly drought stress) are needed.

Soil type significantly affected R:S ratios, numbers of leaves, and height in the shorter-term trial, but had no significant effects on plant growth in the longer-term trial (Table 4). Plant biomass accumulation rates (biomass divided by experiment duration) in the shorter-term trial were generally greater $(p<0.05)$ than those in the longer-term trial (data not shown). Additionally, plants (particularly, $P$. glandulosa and B. eriopoda) produced more leaves, grew taller, and had greater R:S ratios when growing on winnowed soils in the shorter-term trial. These results indicate the plants exhibited faster growth in the shorter-term trial. In this trial, seedling growth would have been influenced by more nutrients from seed reserves than from soils (e.g., Bouaziz and Hicks 1990; Milberg and Lamont 1997). Whereas in the longer-term trial, seedling growth would have transitioned from reliance on nutrient stored in the seed to a dependence of soil nutrients. Accordingly, nutrients may have been less of a limiting factor during the shorter-term trial and seedlings may have benefitted from the greater water availability on winnowed soils. Furthermore, seedlings of shrubs with greater seed mass (particularly $P$. glandulosa and A. canescens) would have greater nutrient stores to draw from and could accordingly maximize their initial below/aboveground development compared to small-seeded grass species (Milberg and Lamont 1997; Milberg et al. 1998), thus providing an advantage for establishment on nutrient-depleted soils.

The magnitude of within-species differences in morphological characteristics on the two soil types diminished in the longer-term trial compared to the 
shorter-term trial. For example, the only significant difference in aboveground biomass on the contrasting soils in the longer-term trial was for the grass A. purpurea, whereas we documented differences for all grass and one shrub species (A. canescens) in the shorter-term trial (Fig. 4). As mentioned in the previous paragraph, in the longer-term trial, plants could eventually derive nutrients solely from the soil, thus nutrient availability would be a more important factor for plant growth than in the shorter-term trial. Desorption curves indicate that winnowed soils would maintain higher levels of plant-available water as soils dry, but the non-winnowed soils had higher nutrient contents. As such, in the shorter-term trial where seedlings may have been deriving nutrients primarily from the seed, water would have been the primary limiting resource; in the longer-term trial where plants would have transitioned to obtaining nutrients from the soil, both water and nutrients may have been colimiting. Further research regarding how the transition from seed- to soil-based nutrition influences seedling establishment among grass and shrub species may shed light on mechanisms regulating plant recruitment on winnowed vs. non-winnowed soils.

Plant functional group had significant effects on most plant morphological and growth characteristics in both trials (Table 4). Shrubs commonly outperformed grasses in both trials; this was especially so for $P$. glandulosa, which had the highest above- and belowground biomass of all species (Fig. 4). Because $\mathrm{C}_{4}$ species typically have higher nitrogen/water use efficiencies than $\mathrm{C}_{3}$ species (Pearcy and Ehleringer 1984; Sage 2004), they should perform better on resourcedepleted winnowed soils. This was inconsistently supported among shrub species, where the $\mathrm{C}_{4}$ A. canescens produced more biomass than the $\mathrm{C}_{3}$ L. tridentata but less than the $\mathrm{C}_{3} P$. glandulosa. These photosynthetic pathway comparisons are confounded by the fact that $P$. glandulosa is deciduous with the potential for symbiotic $\mathrm{N}_{2}$-fixation (Monks et al. 2012; Zahran 1999; Zitzer et al. 1996), whereas L. tridentata is an evergreen "true xerophyte" with an inherently slow growth rate (Cody 2000; Lajtha and Whitford 1989). It should be kept in mind that species comparisons in this study were conducted without consideration of plant-plant interactions.

\section{Conclusions}

Overall, our greenhouse bioassay results showed seed germination and early seedling growth of contrasting plant functional groups on winnowed soils were not adversely nor differentially impacted relative to that observed on non-winnowed soils under well-watered conditions. Field trials are needed to ascertain if the results obtained in our greenhouse experiments hold up under field conditions where factors like seasonal temperature and moisture stress, seed burial depth, seed/seedling predation, plant-plant interactions, etc. are at play.

$P$. glandulosa shrubs started and completed germination more rapidly than other grass and shrub species used in our trials and produced the greatest total biomass. Rapid germination/emergence and early rapid growth would give $P$. glandulosa shrubs potential recruitment advantages over grasses and other shrub species and helps explain its widespread, successful proliferation within southern Great Plains and Chihuahuan Desert grasslands of North America (Barger et al. 2011).

Acknowledgements This study was supported by USA National Science Foundation (NSF DEB-1556587 and 1556735) and the Jornada Basin Long-Term Ecological Research Program (DEB 12-35828, 18-32194). We extend thanks to Dr. Katharine Predick for her suggestions and comments on the early version of the manuscript, and to the staff at the Jornada Experimental Range headquarters for logistical support and to our Jornada LTER collaborators.

Author contributions All authors contributed to the study conception and design. Material preparation, data collection and analysis were performed by Furong Niu and Nathan A. Pierce. The manuscript was written by Furong Niu and Nathan A. Pierce and all authors reviewed and edited on previous versions of the manuscript. All authors read and approved the final manuscript.

Funding This study was supported by USA National Science Foundation (NSF DEB-1556587 and 1556735) and the Jornada Basin Long-Term Ecological Research Program (DEB 12-35828, 18-32194).

Data availability The datasets generated during the current study are available from the corresponding author on reasonable request.

Code availability The code used in this study is available from the corresponding author on reasonable request. 


\section{Declarations}

Ethics approval (include appropriate approvals or waivers) Not applicable.

\section{Consent to participate (include appropriate state- ments) Not applicable.}

\section{Consent for publication (include appropriate state- ments) Not applicable.}

Conflicts of interest/Competing interests The authors declare no conflicts of interests/competing interests.

Open Access This article is licensed under a Creative Commons Attribution 4.0 International License, which permits use, sharing, adaptation, distribution and reproduction in any medium or format, as long as you give appropriate credit to the original author(s) and the source, provide a link to the Creative Commons licence, and indicate if changes were made. The images or other third party material in this article are included in the article's Creative Commons licence, unless indicated otherwise in a credit line to the material. If material is not included in the article's Creative Commons licence and your intended use is not permitted by statutory regulation or exceeds the permitted use, you will need to obtain permission directly from the copyright holder. To view a copy of this licence, visit http://creativecommons.org/licenses/by/4.0/.

\section{References}

Alvarez LJ, Epstein HE, Li J, Okin GS (2012) Aeolian process effects on vegetation communities in an arid grassland ecosystem. Ecol Evol 2:809-821. https://doi.org/10.1002/ ece 3.205

Anadón JD, Sala OE, Turner BL, Bennett EM (2014) Effect of woody-plant encroachment on livestock production in North and South America. Proc Natl Acad Sci U S A 111:12948-12953. https://doi.org/10.1073/pnas.13205 85111

Archer S, Schimel DS, Holland EA (1995) Mechanisms of shrubland expansion: land use, climate or $\mathrm{CO}_{2}$ ? Clim Change 29:91-99. https://doi.org/10.1007/BF01091640

Archer SR, Andersen EM, Predick KI et al (2017) Woody plant encroachment: causes and consequences. In: Briske DD (ed) Rangeland systems: processes, management and challenges. Springer, Cham, pp 25-84

Armbrust DV, Retta A (2000) Wind and sandblast damage to growing vegetation. Ann Arid Zone 39:273-284

Barger NN, Archer SR, Campbell JL et al (2011) Woody plant proliferation in North American drylands: A synthesis of impacts on ecosystem carbon balance. J Geophys Res Biogeosciences 116:1-17. https://doi.org/10.1029/2010J G001506
Belnap J, Munson SM, Field JP (2011) Aeolian and fluvial processes in dryland regions: the need for integrated studies. Ecohydrology 4:615-622. https://doi.org/10.1002/eco.258

Benvenuti S (2003) Soil texture involvement in germination and emergence of buried weed seeds. Agron J 95:191198. https://doi.org/10.2134/agronj2003.0191

Benvenuti S (2007) Natural weed seed burial: Effect of soil texture, rain and seed characteristics. Seed Sci Res 17:211219. https://doi.org/10.1017/S0960258507782752

Berg A, Findell K, Lintner B et al (2016) Land-atmosphere feedbacks amplify aridity increase over land under global warming. Nat Clim Chang 6:869-874. https://doi.org/10. 1038/nclimate3029

Bouaziz A, Hicks DR (1990) Consumption of wheat seed reserves during germination and early growth as affected by soil water potential. Plant Soil 128:161-165. https:// doi.org/10.1007/BF00011105

Brown JR, Archer S (1987) Woody plant seed dispersal and gap formation in a North American subtropical savanna woodland: the role of domestic herbivores. Vegetatio 73:73-80. https://doi.org/10.1007/BF00031854

Campbell GS, Shiozawa S (1992) Prediction of hydraulic properties of soils using particle size distribution and bulk density data. In: van Genuchten MT, Leij FJ, Lund LJ (eds) Proceedings of international workshop on indirect methods for estimating the hydraulic properties of unsaturated soils. University of California, Riverside, pp 317-328

Campbell GS, Smith DM, Teare BL (2007) Application of a dew point method to obtain the soil water characteristic. In: Schanz T (ed) Experimental unsaturated soil mechanics. Springer, Heidelberg, pp 71-75

Chachalis D, Reddy KN (2000) Factors affecting Campsis radicans seed germination and seedling emergence. Weed Sci 48:212-216. https://doi.org/10.1614/0043-1745(2000) 048[0212:facrsg]2.0.co;2

Chambers JC, Macmahon JA, Haefner JH (1991) Seed entrapment in alpine ecosystems: effects of soil particle size and diaspore morphology. Ecology 72:1668-1677. https://doi. org/10.2307/1940966

Cody ML (2000) Slow-motion population dynamics in Mojave Desert perennial plants. J Veg Sci 11:351-358. https://doi. org/10.2307/3236627

Cook ER, Woodhouse CA, Eakin CM et al (2004) Long-term aridity changes in the western United States. Science 306:1015-1018. https://doi.org/10.1126/science.1102586

Eldridge DJ, Bowker MA, Maestre FT et al (2011) Impacts of shrub encroachment on ecosystem structure and functioning: Towards a global synthesis. Ecol Lett 14:709-722. https://doi.org/10.1111/j.1461-0248.2011.01630.x

El-Keblawy A (2017) Light and temperature requirements during germination of potential perennial grasses for rehabilitation of degraded sandy Arabian Deserts. L Degrad Dev 8:1687-1695. https://doi.org/10.1002/ldr.2700

Fravolini A, Hultine KR, Brugnoli E et al (2005) Precipitation pulse use by an invasive woody legume: the role of soil texture and pulse size. Oecologia 144:618-627. https:// doi.org/10.1007/s00442-005-0078-4

Gibbens RP, McNeely RP, Havstad KM et al (2005) Vegetation changes in the Jornada Basin from 1858 to 1998. J Arid 
Environ 61:651-668. https://doi.org/10.1016/j.jaridenv. 2004.10.001

Gillette DA, Chen W (2001) Particle production and aeolian transport from a "supply-limited" source area in the Chihuahuan desert, New Mexico, United States. J Geophys Res Atmos 106:5267-5278. https://doi.org/10.1029/2000J D900674

Givnish TJ (2002) Adaptive significance of evergreen vs. deciduous leaves: solving the triple paradox. Silva Fenn 36:703-743. https://doi.org/10.14214/sf.535

Grossman RB, Reinsch TG (2002) Bulk density and linear extensibility. In: Dane JH, Topp CG (eds) Methods of soil analysis: part 4 physical methods. Soil Science Society of America, Madison, WI, pp 201-208

Hibbard KA, Archer S, Schimel DS, Valentine DW (2001) Biogeochemical changes accompanying woody plant encroachment in a subtropical savanna. Ecology 82:19992011. https://doi.org/10.2307/2680064

Huang Z, Liu S, Bradford KJ et al (2016) The contribution of germination functional traits to population dynamics of a desert plant community. Ecology 97:250-261. https://doi. org/10.1890/15-0744.1

Jones HG (2007) Monitoring plant and soil water status: Established and novel methods revisited and their relevance to studies of drought tolerance. J Exp Bot 58:119-130. https://doi.org/10.1093/jxb/erl118

Khan MA, Gulzar S (2003) Light, salinity, and temperature effects on the seed germination of perennial grasses. Am J Bot 90:131-134. https://doi.org/10.3732/ajb.90.1.131

Knapp AK, Briggs JM, Collins SL et al (2008) Shrub encroachment in North American grasslands: Shifts in growth form dominance rapidly alters control of ecosystem carbon inputs. Glob Chang Biol 14:615-623. https://doi.org/10. 1111/j.1365-2486.2007.01512.x

Lajtha K, Whitford WG (1989) The effect of water and nitrogen amendments on photosynthesis, leaf demography, and resource-use efficiency in Larrea tridentata, a desert evergreen shrub. Oecologia 80:341-348. https://doi.org/10. 1007/BF00379035

Lal R (2001) Soil degradation by erosion. L Degrad Dev 12:519-539. https://doi.org/10.1002/ldr.472

Leishman M, Wright I, Moles A, Westoby M (2000) The evolutionary ecology of seed. In: Fenner M (ed) The ecology of regeneration in plant communities. CAB International, London, pp 31-57

Li J, Okin GS, Alvarez L, Epstein H (2007) Quantitative effects of vegetation cover on wind erosion and soil nutrient loss in a desert grassland of southern New Mexico, USA. Biogeochemistry 85:317-332. https://doi.org/10.1007/ s10533-007-9142-y

Li J, Okin GS, Alvarez L, Epstein H (2008) Effects of wind erosion on the spatial heterogeneity of soil nutrients in two desert grassland communities. Biogeochemistry 88:73-88. https://doi.org/10.1007/s10533-008-9195-6

Li J, Okin GS, Alvarez LJ, Epstein HE (2009) Sediment deposition and soil nutrient heterogeneity in two desert grassland ecosystems, southern New Mexico. Plant Soil 319:67-84. https://doi.org/10.1007/s11104-008-9850-7

Madany MH, West NE (1983) Livestock grazing- fire regime interactions within montane forests of Zion National Park,
Utah. Ecology 64:661-667. https://doi.org/10.2307/19371 86

McCulley RL, Archer SR, Boutton TW et al (2004) Soil respiration and nutrient cycling in wooded communities developing in grassland. Ecology 85:2804-2817. https://doi. org/10.1890/03-0645

McNair JN, Sunkara A, Frobish D (2012) How to analyse seed germination data using statistical time-to-event analysis: Non-parametric and semi-parametric methods. Seed Sci Res 22:77-95. https://doi.org/10.1017/S09602585110005 47

Merino-Martín L, Courtauld C, Commander L et al (2017) Interactions between seed functional traits and burial depth regulate germination and seedling emergence under water stress in species from semi-arid environments. J Arid Environ 147:25-33. https://doi.org/10.1016/j.jarid env.2017.07.018

Milberg P, Lamont BB (1997) Seed/cotyledon size and nutrient content play a major role in early performance of species on nutrient-poor soils. New Phytol 137:665-672. https:// doi.org/10.1046/j.1469-8137.1997.00870.x

Milberg P, Pérez-Fernández MA, Lamont BB (1998) Seedling growth response to added nutrients depends on seed size in three woody genera. J Ecol 86:624-632. https://doi.org/ 10.1046/j.1365-2745.1998.00283.x

Monger HC, Mack GH, Nolen BA, Gile LH (2006) Regional setting of the Jornada LTER. In: Havstad KM, Huenneke LF (eds) Structure and function of a Chihuahuan Desert ecosystem: the Jornada Basin Long-term Ecological Research Site. Oxford University Press, New York, pp $15-43$

Monks A, Cieraad E, Burrows L, Walker S (2012) Higher relative performance at low soil nitrogen and moisture predicts field distribution of nitrogen-fixing plants. Plant Soil 359:363-374. https://doi.org/10.1007/s11104-012-1170-2

Nearing MA, Pruski FF, O’Neal MR (2004) Expected climate change impacts on soil erosion rates: a review. J Soil Water Conserv 59:43-50

Nearing MA, Xie Y, Liu B, Ye Y (2017) Natural and anthropogenic rates of soil erosion. Int Soil Water Conserv Res 5:77-84. https://doi.org/10.1016/j.iswcr.2017.04.001

Okin GS, Sala OE, Vivoni ER et al (2018) The interactive role of wind and water in functioning of drylands: what does the future hold? Bioscience 68:670-677. https://doi.org/ 10.1093/biosci/biy067

Pearcy RW, Ehleringer J (1984) Comparative ecophysiology of C3 and C4 plants. Plant Cell Environ 7:1-13. https://doi. org/10.1111/j.1365-3040.1984.tb01194.x

Pierce NA, Archer SR, Bestelmeyer BT (2019a) Competition suppresses shrubs during early, but not late, stages of arid grassland-shrubland state transition. Funct Ecol 33:1480 1490. https://doi.org/10.1111/1365-2435.13336

Pierce NA, Archer SR, Bestelmeyer BT, James DK (2019b) Grass-shrub competition in arid lands: An Overlooked driver in grassland-shrubland state transition? Ecosystems 22:619-628. https://doi.org/10.1007/s10021-018-0290-9

R Core Team (2020) R: A language and environment for statistical computing. R Foundation for Statistical Computing, Vienna, Austria. https://www.R-project.org/

Ranal MA, de Santana DG, Ferreira WR, Mendes-Rodrigues C (2009) Calculating germination measurements and 
organizing spreadsheets. Rev Bras Botânica 32:849-855. https://doi.org/10.1590/s0100-84042009000400022

Ratajczak Z, Nippert J, Collins S (2012) Woody encroachment decreases diversity across North American grasslands and savannas. Ecology 93:697-703. https://doi.org/10.1890/ 11-1199.1

Reynolds HG, Glendening GE (1949) Merriam kangaroo rat as a factor in mesquite propagation on southern Arizona rangelands. J Range Manage 2:193-197

Saatkamp A, Cochrane A, Commander L et al (2019) A research agenda for seed-trait functional ecology. New Phytol 221:1764-1775. https://doi.org/10.1111/nph.15502

Sage RF (2004) The evolution of C4 photosynthesis. New Phytol 161:341-370. https://doi.org/10.1111/j.1469-8137. 2004.00974.x

Schlesinger WH, Reynolds JF, Cunningham GL et al (1990) Biological feedbacks in global desertification. Science 247:1043-1048. https://doi.org/10.1126/science.247. 4946.1043

Therneau, TM (2015) A package for survival analysis in S. https://cran.r-project.org/package=survival. Accessed 18 May 2021

Traba J, Azcárate FM, Peco B (2004) From what depth do seeds emerge? A soil seed bank experiment with
Mediterranean grassland species. Seed Sci Res 14:297303. https://doi.org/10.1079/ssr2004179

USDA Soil Science Division Staff (2017) USDA soil survey manual. Washington, D.C.

Van Auken OW (2000) Shrub invasions of North American semiarid grasslands. Annu Rev Ecol Syst 31:197-215. https://doi.org/10.1146/annurev.ecolsys.31.1.197

Wright IJ, Reich PB, Westoby M et al (2004) The worldwide leaf economics spectrum. Nature 428:821-827. https:// doi.org/10.1038/nature02403

Young JA, Young CG (1992) Seeds of woody plants in North America. Dioscorides Press, Portland, OR

Zahran HH (1999) Rhizobium-legume symbiosis and nitrogen fixation under severe conditions and in an arid climate. Microbiol Mol Biol Rev 63:968-989. https://doi.org/10. 1128/mmbr.63.4.968-989.1999

Zitzer SF, Archer SR, Boutton TW (1996) Spatial variability in the potential for symbiotic $\mathrm{N}_{2}$ fixation by woody plants in a subtropical savanna ecosystem. J Appl Ecol 33:1125. https://doi.org/10.2307/2404692

Publisher's note Springer Nature remains neutral with regard to jurisdictional claims in published maps and institutional affiliations. 